\title{
GASTRIC CANCER TRENDS IN EPIDEMIOLOGY
}

Zilberstein B, Jacob CE, Cecconello I. Gastric cancer trends in epidemiology. Arq Gastroenterol. 2012;49(3):177-8.

HEADINGS - Stomach neoplasms, epidemiology.

Stomach cancer is a very malignant challenge being the forth most common cancer worldwide. In Brazil the incidence is still important mainly among men ${ }^{(2)}$. Its incidence varies widely around the world in a way that our current understanding of etiology cannot fully explain. It is admitted and described that its incidence has been decreasing in most industrialized countries over the past 3 decades. In spite of this favorable trend, a large geographical variability in both incidence and mortality rates still persists. There is a substantial variation in patients' survival among Eastern (Japan, Korea, and China) and Western countries. Even in the West world different survival rates are reported when we compare the results in the United States and European countries, like Italy and Germany where the Japanese rules were been accepted over the last decades. It is important to emphasize that the results of surgical treatment are better in some US high volume centers dedicated to gastric cancer research.

All those findings are due to the enormous difference not only in etiology but also in early detection, specialized treatment and for sure prevention. In fact, etiology is a challenge in understanding and improving the prevention and surveillance programs.

Over the last 2 decades, an evolutionary approach to the introduction of early diagnosis strategies, surveillance programs, different types of surgery, and adjuvant treatments has been adopted ${ }^{(1,5)}$.

Gastric cancer has a multifactorial etiology. The incidence thought to be strongly influenced by both exogenous and unknown endogenous factors. Several risk factors have been described as important to disease development. Among risk factors can be mentioned blood type A, familial history of gastric cancer, pernicious anemia, histological modifications of gastric remnant after resection for benign diseases, genetic or genes modifications, and environmental factors ${ }^{(8)}$.

Gastric carcinogenesis is also correlated with high sodium chloride diets, water and food consumptions with high amounts of nitrous compounds, poor consumption of vitamins $\mathrm{C}, \mathrm{E}$ and beta-caroten diets, and for sure one of the most greater villain, the inflammatory response to Helicobacter pylori infection. Those influences were well established studying migratory populations who have changed their alimentary habits and where gastric cancer incidence decreased. The influence of $H$ pylori infection and other exogenous factors, such as nutrition, food conservation, additives, and a low socio-economic status are specially important in high incidence areas like Latin America and Asia.
In low incidence areas genetic and biological seems to have higher influence in gastric cancer development. Family history of gastric cancer or non-polyposis colon cancer syndrome, blood type A are also implicated in incidence.

In the "Hospital das Clinicas of São Paulo University Medical School", we develop an epidemiologic prospective study analyzing the association of $\mathrm{H}$ pylori infection and gastric cancer. The seroprevalence of $H$ pylori was not significantly different in gastric cancer patients $(91 \%)$ in relation to the control group (79\%); neither was among the control (79\%), the diffuse-type gastric cancer $(80 \%)$ and the intestinal-type gastric cancer (100\%) groups. By the contrary the comparison of the intestinal-type gastric cancer ( $100 \%$ H pylori positive) with its correspondent control subject ( $68 \%$ H pylori positive) was statistically significant $(P=0.008)$. We conclude that in spite of the prevalence of $\mathrm{H}$ pylori in Brazil being high, the correlation of $\mathrm{H}$ pylori infection to gastric cancer could be statistically demonstrated only for the intestinal-type. Therefore we do strongly believe that this correlation should be better studied before blaming the $\mathrm{H}$ pylori for all the evils ${ }^{(6)}$.

Several changes are been reported in gastric cancer epidemiology in the last decades probably due to changes in exogenous factors ${ }^{(9)}$. These changes are also the explanation to the worldwide declining trend in stomach cancer incidence. Decrease of distal lesions and increase of proximal and cardia tumors have been described since the early eighties. We observed the same in Brazil, where the number of proximal tumors increase in more than $300 \%$ when we compare the results in last years. An increase of diffuse type lesions and early gastric cancers were reported in several countries, including Brazil(4).

Brazil represents the mixture of all tendencies being a cauldron where all etiologics factors can be found depending of the geographical situation with its socio-cultural problems and habits. We need more studies about the epidemiology of this disease with special interest in habits of Brazilian population.

The studies published in this issue of ARQUIVOS de GASTROENTEROLOGIA ${ }^{(3,7)}$ reflects these tendency and therefore all the efforts should be developed in better sanitary health efforts to improve health conditions and educational measures must be taken to teach, show and change alimentary habits.

Bruno ZILBERSTEIN Carlos Eduardo JACOB Ivan CECCONELLO

Department of Gastroenterology - University of Sao Paulo School of Medicine, São Paulo, Brazil. 
Zilberstein B, Jacob CE, Cecconello I. Epidemiologia do câncer gástrico - tendências. Arq Gastroenterol. 2012;49(3):177-8

DESCRITORES - Neoplasias gástricas, epidemiologia.

\section{REFERENCES}

1. Gama-Rodrigues J. Tratamento do câncer gástrico. In: Habr-Gama A, Gama-Rodrigues J, Bettarello A, editors. Câncer do estômago e intestino delgado: prevenção e detecção. São Paulo: EPU/EDUSP; 1980. p. 355-62.

2. Guerra MR, Moura Gallo CV, Silva Mendonça GA. Risco de câncer no Brasil: tendências e estudos epidemiológicos mais recentes. Rev Bras Cancerol. 2005;51: 227-34.

3. Guimarães RM, Muzi CD. Trend of mortality rates for gastric cancer in Brazil and regions in the period of 30 years (1980-2009). Arq Gastroenterol. 2012;49:184-8.

4. Jacob CE, Gama-Rodrigues J, Bresciani CJ, Zilberstein B, Proscurshim I, Iriya $\mathrm{K}$, Alves VA, Cecconello I. Trends in tumor location in gastric carcinoma over a 28-year period. Hepatogastroenterology. 2007;54:1297-301.
5. Jacob CE, Bresciani CJC, Gama-Rodrigues JJ, Yagi OK, Mucerino D, Zilberstein B, Cecconello I. Behavior of gastric cancer in Brazilian population. ABCD Arq Bras Cir Dig. 2009;22:29-32.

6. Mattar R, Monteiro MS, Marques SB, Zilberstein B, Hashimoto CL, Carrilho FJ. Association of LEC and tnpA Helicobacter pylori genes with gastric cancer in a Brazilian population. Infect Agent Cancer. 2010, 5:1.

7. Rampazzo A, Motta GL, Fontana K, Fagundes RB. Gastric adenocarcinoma trends in the central region of Rio Grande do Sul (Southern Brazil): what has changed in 25 years? Arq Gastroenterol. 2012;49:179-83.

8. Safatle-Ribeiro A, Ribeiro Jr U, Clarke MR, Sakai P, Ishioka S, Garrido Jr AB, Gama-Rodrigues J, Safatle NF, Reynolds JC. Relationship between persistence of Helicobacter pylori and dysplasia, intestinal metaplasia, atrophy, inflammation, and cell proliferation following partial gastrectomy. Dig Dis Sci. 1999;44:243-52

9. Verdecchia A, Mariotto A, Gattab G, Bustamante-Teixeira MB, Ajiki W. Comparison of stomach cancer incidence and survival in four continents. Eur $\mathrm{J}$ Cancer. 2003;39:1603-9. 